\title{
Tingkat Pengetahuan, Sikap dan Perilaku Petani dalam Pengelolaan Konservasi Musuh Alami sebagai Upaya Pengendalian Tungro di Kalimantan Selatan
}

\section{Level of Knowledge, Attitude and Behavior of Farmers in Managing Conservation of Natural Enemies as Tungro Control Efforts in South Kalimantan}

\author{
Elisurya Ibrahim $^{1 *}$, Diah Arina Fahmi ${ }^{1}$, Yayan Suryana ${ }^{2}$ \\ ${ }^{1}$ Loka Penelitian Penyakit Tungro, Sidrap, Sulawesi Selatan 91651 \\ ${ }^{2}$ Balai Pengkajian Teknologi Pertanian (BPTP) Sumatera Selatan, \\ Palembang, Sumatera Selatan 30151 \\ ${ }^{*}$ Penulis untuk korespondensi: elisuryaibrahim@gmail.com
}

\begin{abstract}
Efforts to secure and maintain food self-sufficiency, especially rice that has been achieved by the government, need to be done. One of them is by controlling plant pests and diseases. Another effort that can be done is to utilize the potential of suboptimal land such as swamps, in addition to optimizing irrigated and rainfed rice fields. Tungro is an important disease that can be threaten rice productivity. Conservation of natural enemies as one method of tungro control needs to be studied at the farmer level. The purposes of this study were to examine the level of knowledge, attitudes and behavior of farmers in the conservation management of natural enemies in swamps. This research was conducted at Guntung Ujung, Banjar District South Kalimantan on August 2017. Site selection was carried out by purposive sampling because the location was one of the tungro endemic areas in 2014. The primary data collection method using interviews used questionnaires on 37 respondents farmers, while secondary data was obtained from relevant agencies. Data analysis method uses qualitative descriptive analysis by presenting scoring. The results showed that the level of knowledge of farmers on the management of conservation of natural enemies included in the medium category (64.13\%), as well as the attitude of farmers towards the management of conservation of natural enemies included in the medium category $(65.77 \%)$. The behavior of farmers in supporting the management of conservation of natural enemies is also included in the medium category $(53.67 \%)$.
\end{abstract}

Keywords: tungro, Conservation, Natural enemies, Swamp Land

\section{ABSTRAK}

Upaya mengamankan dan mempertahankan swasembada pangan khususnya beras yang telah dicapai kembali oleh pemerintah perlu dilakukan. Salah satunya dengan pengendalian hama dan penyakit tanaman. Upaya lain yang dapat dilakukan adalah dengan memanfaatkan potensi lahan suboptimal seperti lahan rawa, disamping mengotimalkan lahan sawah irigasi dan tadah hujan. Tungro merupakan salah satu penyakit penting yang dapat mengancam produktivitas padi. Konservasi musuh alami sebagai salah satu metode pengendalian tungro perlu dikaji penerapannya di tingkat petani. Penelitian ini bertujuan untuk mengkaji tingkat pengetahuan, sikap dan perilaku petani dalam pengelolaan konservasi musuh alami di lahan rawa Kabupaten Banjar, Kalimantan Selatan. Lokasi penelitian bertempat di Desa Guntung Ujung, Kecamatan Gambut, Kabupaten Banjar, Provinsi Kalimantan Selatan yang dilaksanakan pada Agustus 2017. Pemilihan lokasi 
dilakukan secara purposive sampling karena lokasi tersebut merupakan salah satu yang pernah menjadi daerah endemis tungro pada tahun 2014. Metode pengambilan data primer dengan wawancara menggunakan kuesioner pada 37 orang petani responden, sedangkan data sekunder diperoleh dari instansi terkait. Metode analisis data menggunakan analisis deskriptif kualitatif dengan menyajikan skoring. Hasil Penelitian menunjukkan bahwa tingkat pengetahuan petani terhadap pengelolaan konservasi musuh alami temasuk dalam kategori sedang $(64,13 \%)$, begitu pula sikap petani terhadap pengelolaan konservasi musuh alami termasuk dalam kategori sedang $(65,77 \%)$. Perilaku petani dalam mendukung pengelolaan konservasi musuh alami juga masuk dalam kategori sedang $(53,67 \%)$.

Kata kunci: tungro, Konservasi, Musuh Alami, Lahan Rawa

\section{PENDAHULUAN}

Keberhasilan Indonesia dalam meraih kembali swasembada pangan khususnya beras, perlu terus dikawal dan dipertahankan. Salah satu upaya yang bisa dilakukan adalah pemantauan dan pengendalian terhadap hama dan penyakit tanaman pangan, khususnya padi. Tungro merupakan salah satu penyakit tanaman padi yang sangat penting karena dampaknya dapat mengancam produktivitas padi. Disisi lain tantangan dalam peningkatan produksi beras nasional salah satunya yaitu alih fungsi lahan optimal menjadi pemukiman dan infrastruktur lainnya, sehingga perlu ada pemanfaatan lahan-lahan sub optimal misalnya lahan rawa. Pemanfaatan lahan rawa sebagai lahan sawah dihadapkan dengan masalah kondisi tanah dengan tingkat kesuburan yang rendah dan juga adanya serangan hama dan penyakit, salah satunya yaitu penyakit tungro. Wakid dan Syahbuddin (2013) mengungkapkan bahwa lahan rawa di Indonesia terdapat sekitar 33.4 juta hektar dan tersebar di 16 Provinsi. Pada 11 Provinsi potensial termasuk Kalimantan Selatan dan Sumatera Selatan yang memiliki lahan rawa terluas dan mampu menambah produksi GKG sebesar 3,5 juta ton dari lahan seluas 2,78 juta hektar melalui peningkaran Indeks Pertanaman (IP).

Berdasarkan data dari BPTPH Kalimantan Selatan, tungro yang dikenal oleh masyarakat Kalimantan Selatan sebagai penyakit habang, pada tahun 2006 menyerang beberapa kecamatan di Barito Koala dan telah menimbulkan kerugian yang cukup besar bagi petani. Hingga pada tahun 2009 virus tungro telah menyebar ke berbagai daerah lain di Kalimantan Selatan. Serangan penyakit tungro dapat menurunkan produksi, bahkan dapat menyebabkan puso terutama di daerahdaerah endemis tungro, salah satunya di Kalimantan Selatan yang terjadi pada tahun 2014 (Yoandestina, 2013).

Salah satu alternatif pengendalian tungro yaitu dengan mengeliminir wereng hijau (Nephotetix virescens) yang berperan sebagai vektor tungro dengan pemanfaatan atau pengelolaan konservasi musuh alami. Musuh alami adalah organisme di alam yang dapat melemahkan atau membunuh serangga, sehingga dapat mengakibatkan kematian pada serangga, dan mengurangi fase reproduktif dari serangga. Musuh alami berperan dalam menurunkan populasi hama sampai pada tingkat populasi yang tidak merugikan (Untung, 1992). Potensi pengembangan konservasi pengendalian biologis menjadi dipertimbangkan, terutama pada wereng hijau. Keterpaduan antara penggunaan varietas dan pengelolaan musuh alami diharapkan akan membentuk keseimbangan alami dan diperoleh hasil yang stabil tinggi (Senoaji dan Praptana, 2015). Pengendalian Penyakit Tungro juga harus dilakukan secara komperehensif dengan memperhatikan berbagai aspek seperti penyebaran virus tungro, fluktuasi populasi wereng hijau, perubahan kondisi lingkungan dan sosial ekonomi petani (Hasanuddin et.al, 2001 dalam Pakki, 
2010). Penelitian ini bertujuan untuk mengkaji tingkat pengetahuan, sikap dan perilaku petani dalam pengelolaan konservasi musuh alami di lahan rawa Kabupaten Banjar, Provinsi Kalimantan Selatan.

\section{BAHAN DAN METODE}

Penelitian dilaksanakan pada Agustus 2017. Lokasi penelitian bertempat di Desa Guntung Ujung, Kecamatan Gambut, Kabupaten Banjar, Provinsi Kalimantan Selatan. Pemilihan lokasi dilakukan secara purposive sampling karena lokasi tersebut merupakan salah satu yang pernah menjadi daerah endemis tungro pada tahun 2014. Sampel yang diambil sebanyak 37 orang (responden) yang merupakan anggota kelompok tani. Pengambilan data primer dilakukan dengan metode wawancara menggunakan bantuan kuesioner yang telah disiapkan. Sedangkan data sekunder diperoleh dari Desa, BPP, BPTPH dan instansi terkait lainnya. Analisis data dengan menggunakan statistik sederhana, skoring dan interpretasi kualitatif terhadap jawaban yang dikemukakan oleh petani responden.

\section{HASIL}

\section{Aspek Pengetahuan}

Aspek pengetahuan petani terhadap konservasi musuh alami yang diteliti adalah pengetahuan tentang hama dan jenisjenisnya, pengetahuan tentang wereng hijau sebagai vektor penyakit tungro serta pengetahuan tentang musuh alami dan jenis-jenisnya (Tabel 1).

Tabel 1. Pengetahuan petani tentang hama dan musuh alami.

\begin{tabular}{|c|c|c|c|c|}
\hline No & Indikator & Jawaban & Jumlah Responden & $\%$ \\
\hline \multirow[t]{3}{*}{1.} & Pengetahuan tentang Hama & Tahu & 20 & 54,05 \\
\hline & & Ragu-ragu & 16 & 43,24 \\
\hline & & Tidak Tahu & 1 & 2,70 \\
\hline \multirow[t]{2}{*}{2.} & Dapat menyebutkan Jenis- & Dapat menyebutkan & 35 & 94,59 \\
\hline & Jenis Hama Padi & Tidak dapat menyebutkan & 2 & 5,41 \\
\hline \multirow[t]{3}{*}{3.} & Pengetahuan tentang & Tahu & 13 & 35,14 \\
\hline & wereng hijau sebagai & Ragu-ragu & 1 & 2,70 \\
\hline & vektor Penyakit Tungro & Tidak Tahu & 23 & 62,16 \\
\hline \multirow[t]{3}{*}{4.} & Pengetahuan tentang & Tahu & 12 & 32,43 \\
\hline & Musuh Alami & Ragu-ragu & 6 & 16,22 \\
\hline & & Tidak Tahu & 19 & 51,35 \\
\hline \multirow[t]{2}{*}{5.} & Dapat menyebutkan Jenis- & Dapat menyebutkan & 13 & 35,14 \\
\hline & Jenis Musuh Alami & Tidak dapat menyebutkan & 24 & 64,86 \\
\hline \multicolumn{5}{|c|}{ Tingkat Pengetahuan Petani Terhadap Konservasi Musuh Alami } \\
\hline & Rendah & & 1 & 2,70 \\
\hline & Sedang & & 34 & 91,89 \\
\hline & Tinggi & & 2 & 5,41 \\
\hline
\end{tabular}

\section{Aspek Sikap}

Aspek sikap petani terhadap pengelolaan konservasi musuh alami (Tabel 2) yang diteliti adalah sikap tentang pentingnya konservasi musuh alami, sikap tentang konservasi musuh alami dengan menanam bunga di pematang, sikap tentang konservasi musuh alami dengan menanam palawija di pematang dan respon petani terhadap pengendalian hama dengan menggunakan pestisida nabati. 
Tabel 2. Sikap petani terhadap pengelolaan konservasi musuh alami.

\begin{tabular}{|c|c|c|c|c|}
\hline No & Indikator & Jawaban & Jumlah Responden & $\%$ \\
\hline \multirow{3}{*}{1.} & \multirow{3}{*}{$\begin{array}{l}\text { Sikap tentang pentingnya } \\
\text { konservasi Musuh Alami }\end{array}$} & Setuju & 8 & 21,62 \\
\hline & & Ragu-ragu & 3 & 8,11 \\
\hline & & Tidak Setuju & 26 & 70,27 \\
\hline \multirow{3}{*}{2.} & Sikap Petani tentang konservasi & Setuju & 22 & 59,46 \\
\hline & Musuh Alami dengan menanam & Ragu-ragu & 4 & 10,81 \\
\hline & bunga di pematang & Tidak Setuju & 11 & 29,73 \\
\hline \multirow{3}{*}{3.} & Sikap Petani tentang konservasi & Setuju & 14 & 37,84 \\
\hline & Musuh Alami dengan menanam & Ragu-ragu & 11 & 29,73 \\
\hline & Palawija di pematang & Tidak Setuju & 12 & 32,43 \\
\hline \multirow[b]{2}{*}{4.} & Respon petani & Suka & 8 & 21,62 \\
\hline & $\begin{array}{l}\text { pengendalian hama dengan } \\
\text { menggunakan pestisida nabati }\end{array}$ & Tidak suka & 29 & 78,38 \\
\hline \multicolumn{5}{|c|}{ Sikap Petani Terhadap Konservasi Musuh Alami } \\
\hline \multicolumn{3}{|c|}{ Rendah } & 3 & 8,11 \\
\hline \multicolumn{3}{|c|}{ Sedang } & 21 & 56,76 \\
\hline \multicolumn{3}{|c|}{ Tinggi } & 13 & 35,14 \\
\hline
\end{tabular}

Aspek perilaku

Aspek perilaku terhadap

diteliti adalah tindakan pengendalian hama, tindakan melindungi musuh alami dan penggunaan pestisida nabati (Tabel 3).

Tabel 3. Perilaku petani terhadap pengelolaan konservasi musuh alami.

\begin{tabular}{|c|c|c|c|c|}
\hline No & Indikator & Jawaban & Jumlah Responden & $\%$ \\
\hline \multirow{3}{*}{1.} & \multirow{3}{*}{$\begin{array}{l}\text { Tindakan pengendalian } \\
\text { hama }\end{array}$} & Kimia & 19 & 51,35 \\
\hline & & Nabati & 1 & 2,70 \\
\hline & & Lainnya & 17 & 45,95 \\
\hline \multirow{4}{*}{2.} & \multirow{4}{*}{$\begin{array}{l}\text { Tindakan melindungi } \\
\text { Musuh Alami }\end{array}$} & Ada tindakan & 10 & 27,03 \\
\hline & & Ragu-ragu & 12 & 32,43 \\
\hline & & Tidak ada & & \\
\hline & & tindakan & 15 & 40,54 \\
\hline \multirow{2}{*}{3.} & \multirow{2}{*}{$\begin{array}{l}\text { Penggunaan pestisida } \\
\text { nabati }\end{array}$} & Pernah & 10 & 27,03 \\
\hline & & Tidak Pernah & 27 & 72,97 \\
\hline \\
\hline & \multicolumn{2}{|c|}{ Rendah } & 3 & 8,11 \\
\hline & \multicolumn{2}{|l|}{ Sedang } & 24 & 64,86 \\
\hline & \multicolumn{2}{|l|}{ Tinggi } & 10 & 27,03 \\
\hline
\end{tabular}

\section{PEMBAHASAN}

Pengetahun merupakan tahap pertama bagi petani untuk dapat mengadopsi sebelum menentukan sikap dan perilakunya. Ginting (2006) dalam Abdullah (2008) menyatakan bahwa salah satu faktor penyebab sulitnya adopsi teknologi petani adalah pengetahuan petani.
Dimana kurangnya sistem diseminasi teknologi pertanian (penyuluhan/demplot/ gelar teknologi) dan rendahnya tingkat pendidikan/ pengetahuan petani sehingga sulit menterjemahkan manfaat teknologi baru. Dari Tabel 1 dapat diketahui bahwa sebagian besar petani sampel yaitu sebesar $54,5 \%$ mengetahui hama penting yang dapat mengancam pertanaman padi, yang 
ditunjukkan dengan banyaknya petani yaitu sebesar $94,59 \%$ yang bisa menyebutkan jenis-jenis hama tersebut. Pengetahuan petani terhadap wereng hijau sebagian besar petani menyatakan tidak tahu yaitu sebanyak $62,15 \%$, begitu pula dengan musuh alami yaitu sebesar $51,35 \%$. Dari keseluruhan indikator pengetahuan, diketahui bahwa tingkat pengetahuan petani terhadap konservasi musuh alami berada dalam taraf sedang. Hal ini menjadi tugas bagi pendamping petani baik itu penyuluh, pengamat hama, dan lain sebagainya untuk terus melakukan diseminasi teknologi konservasi musuh alami bagi petani sebagai salah satu upaya pengendalian penyakit tungro. Meskipun pada kenyataannya menurut Sunaryo dan Joshi (2003), proses adopsi pengetahuan eksternal dan pengetahuan ilmiah di kalangan petani tidak semudah yang dibayangkan. Sehingga perlu pendekatan-pendekatan khusus untuk mencapai keberhasilan adopsi teknologi pertanian di tingkat petani.

Sikap adalah pilihan atau kesiapan untuk bertindak, apakah itu negatif atau positif (Ardi, 2015). Dari Tabel 3 dapat diketahui bahwa sikap petani tentang pentingnya konservasi musuh alami tergolong rendah. Hal ini menunjukkan bahwa petani belum menyadari manfaat dari adanya musuh alami bagi petanaman yang dapat menjadi teman petani dalam mengendalikan populasi hama khususnya wereng hijau. Meskipun demikian sebanyak $59,46 \%$ petani setuju tentang konservasi musuh alami dengan menanam bunga dipematang, demikian juga sikap petani tentang konservasi musuh alami dengan menanam palawija di pematang sebagian besar setuju yaitu sebesar $37,84 \%$. Hal ini cukup beralasan dimana menanam bunga ataupun palawija disamping memberi manfaat estetika juga dapat memberikan hasil samping berupa palawija bagi petani. Hasil penelitian Chandler et al., (1998) dan Rebek et al., (2005) menunjukkan bahwa penambahan tumbuhan berbunga pada pertanaman dengan sumber keragaman rendah dapat meningkatkan populasi serangga berguna baik itu predator maupun parasitoid. Dengan memanfaatkan populasi predator wereng hijau misalnya dari golongan Arachnidae (Laba-laba) populasi hama dapat ditekan perkembangannya. Shepard et al., (1987) mengemukakan bahwa laba-laba pemburu merupakan predator yang paling rakus dengan kemampuan makan 15-20 ekor nimfa wereng hijau per hari.

Sebanyak $21,62 \%$ petani setuju dengan pengendalian hama dengan menggunakan pestisida nabati, sedangkan $78,36 \%$ petani tidak setuju. Pestisida nabati bersifat mudah terdegradasi di alam (Biodegredable), sehingga residunya pada tanaman dan lingkungan tidak signifikan (Anonim, 2012).

Rogers dan Shoemaker (1986) dalam Mulyandari (2011) menyatakan bahwa perilaku merupakan suatu tindakan nyata yang dapat dilihat dan diamati. Perilaku tersebut terjadi akibat adanya proses penyampaian pengetahuan suatu stimulus sampai ada penentuan sikap untuk bertindak atau tidak bertindak, dan hal ini dapat dilihat dengan pancaindera. Gerungan (1986) dalam Ummi (2011) mengemukakan bahwa pengetahuan merupakan domain yang sangat penting dalam membentuk tindakan seseorang, sebab dari pengalaman dan hasil penelitian, ternyata perilaku yang didasari oleh pengetahuan akan lebih langgeng daripada perilaku yang tidak didasari pengetahuan. Tindakan pengendalian hama sebagian besar menggunakan pestisida kimia $(51,35 \%)$, sedangkan tindakan melindungi musuh alami tidak dilakukan oleh sebagian besar petani $(40,45 \%)$. Dari keseluruhan indikator perilaku, menunjukkan bahwa perilaku petani terhadap konservasi musuh alami berada dalam taraf sedang $(64,86 \%)$. Peningkatan pengetahuan dan perubahan perilaku petani membutuhkan metode pemberdayaan masyarakat karena pengetahuannya sudah baik belum tentu perilakunya juga baik atau sebaliknya. Masyarakat petani berperan aktif untuk belajar bersama menemukan sendiri 
permasalahan yang dihadapi serta dapat memecahkan dan menyelesaikan permasalahannya. Petani diharapkan akan mempraktekkan apa yang diketahui atau disikapinya dengan baik. Notoadmodjo (2007) mengemukakan bahwa perubahan perilaku mengikuti tahap-tahap prose perubahan dari pengetahuan, (knowledge) sikap, (attitude) dan praktik (Practice atau PSP). Peran petani dalam mengembangkan potensi alami sebagai upaya pengendalian hama dan penyakit merupakan hal yang sangat penting. Peran petani tersebut salah satunya yaitu dalam pengelolaan musuh alami dengan menanam tanaman berbunga maupun palawija di sekitar pertanaman. Disamping itu memasuki abad 21, kesadaran akan pertanian ramah lingkungan semakin meningkat, sejalan dengan tuntutan era globalisasi dan perdagangan bebas (Salikin, 2003). Sehingga pertanian di Indonesia dituntut untuk dapat mengikuti perkembangan persaingan global dengan menciptakan pertanian yang ramah lingkungan. Kondisi ini perlu mendapat perhatian dari pemerintah untuk mengembangkan konservasi musuh alami melalui peningkatan sosialisasi dan diseminasi terhadap petani melalui metodemetode pendekatan yang tepat.

\section{KESIMPULAN}

Pengetahuan petani di daerah rawa memiliki pengetahuan yang belum memadai mengenai pengendalian tungro dengan pengelolaan konservasi musuh alami. Sikap petani terhadap konservasi musuh alami tergolong sedang, hal ini didasari oleh pengetahuan petani yang belum terlalu baik mengenai pengelolaan konservasi musuh alami. Begitu juga perilaku petani dalam hal pengelolaan konservasi musuh alami belum terlalu optimal. Kedepan, hal ini menjadi tugas bagi para penyuluh dan perhatian dari dinas setempat agar menyiapkan program diseminasi pengendalian tungro bagi petani dengan pengelolaan konservasi musuh alami. Dengan penambahan wawasan dan pengetahuan petani, diharapkan sikap dan perilaku petani dalam budidaya dapat menekan insiden serangan tungro pada daerah lahan rawa.

\section{UCAPAN TERIMA KASIH}

Ucapan terima kasih disampaikan pada Kepala Loka Penelitian Penyakit Tungro, BPTP Kalimantan Selatan, BPTPH Provinsi Kalimantan Selatan, Penyuluh Kecamatan Gambut Kab. Banjar Provinsi Kalimantan Selatan.

\section{DAFTAR PUSTAKA}

Abdullah A. Peran penyuluhan dan Kelompok tani Ternak Untuk Meningkatkan Adopsi Teknologi dalam Peternakan Sapi Potong. Prosiding Seminar Nasional Sapi Potong. Hal 188-195

Anonim. 2012. Pestisida Nabati. Cetakan III. Bogor: Pusat Penelitian dan Pengembangan Perkebunan.

Ardi M. 2015. Perilaku Petani Tegalan Dalam Meningkatkan Kualitas Lingkungan Di Kabupaten Soppeng. Jurnal Scientific Pinisi 1(1): 13-24

Chandler, Jeff, Corbett A, Lamb C, Long R F, Horton C R, and Stimmann M. 1998. Archive-California Agriculture. California Agriculture 52(5): 23-26.

Mulyandari RSH. 2011. Perilaku Petani Sayuran dalam Memanfaatkan Teknologi Informasi. Jurnal Perpustakaan Pertanian 20(1): 2234

Notoadmodjo S. 2007. Promosi Kesehatan \& Ilmu Perilaku. PT Rineka Cipta, Jakarta.

Pakki S. 2010. Peran Faktor Ekobiologi Terhadap Dinamika Populasi Vektor dan Penyakit Tungro. Prosiding Seminar Ilmiah dan Pertemuan Tahunan PEI dan PFI XX Komisariat Daerah Sulawesi Selatan.

Rebek EJ, Sadof CS, and Hanks LM. 2005. 
Manipulating the Abundance of Natural Enemies in Ornamental Landscapes with Floral Resource Plants. Biological Control 33(2):203-16.

Salikin. 2003. Sistem Pertanian

Berkelanjutan. Kanisius,

Yogyakarta

Senoaji W, Praptana RH. 2015. Perkembangan populasi wereng hijau dan predatornya pada beberapa varietas padi. Jurnal Perlindungan Tanaman Indonesia. 19(1): 65-72.

Shepard B, Borrion AT, Litsinger JA. 1987. Helpful Insects, Spider and Pathogens. IRRI, Los Banos, Philippines.

Sunaryo, Joshi L. 2003. Peranan Pengetahuan Ekologi Lokal dalam
Sistem Agroforestri. Bahan Ajaran 7. World Agroforestry Centre (ICRAF), Southeast Asia Regional Office, Bogor, Indonesia : 28.

Untung K. 2006. Pengantar Pengelolaan Hama Terpadu. Kedua. Yogyakarta: Gadjah Mada University Press.

Wakid N, Syahbuddin H. 2013. Peta Kalender Tanam Padi Lahan Rawa Lebak Kalimantan Selatan di Tengah Perubahan Iklim Global. Jurnal Ilmiah Geometika, 19(1):3229.

Yoandestina. 2013. Penyakit Tungro di Lahan Rawa. http:// http://balittra.litbang.pertanian.go.id /index.php?option=com_content\&vi $\mathrm{ew}=$ article $\& \mathrm{id}=1318 \&$ Itemid $=10$. [Diakses 22 januari 2018]. 